Corrado Neri, Âges inquiets. Cinémas chinois: une représentation de la jeunesse (Uneasy ages. Chinese cinemas: A representation of youth)

Judith Pernin

\title{
CpenEdition
}

Journals

Édition électronique

URL : http://journals.openedition.org/chinaperspectives/5292

DOI : $10.4000 /$ chinaperspectives.5292

ISSN : 1996-4617

Éditeur

Centre d'étude français sur la Chine contemporaine

Édition imprimée

Date de publication : 1 juin 2010

ISSN : 2070-3449

Référence électronique

Judith Pernin, « Corrado Neri, Âges inquiets. Cinémas chinois: une représentation de la jeunesse (Uneasy ages. Chinese cinemas: A representation of youth) », China Perspectives [En ligne], 2010/2 | 2010, mis en ligne le 05 août 2010, consulté le 24 septembre 2020. URL : http://journals.openedition.org/ chinaperspectives/5292; DOI : https://doi.org/10.4000/chinaperspectives.5292

Ce document a été généré automatiquement le 24 septembre 2020

(c) All rights reserved 


\section{Corrado Neri, Âges inquiets. Cinémas chinois: une représentation de la jeunesse (Uneasy ages. Chinese cinemas: A representation of youth)}

Judith Pernin

1 Corrado Neri, Âges inquiets. Cinémas chinois: une représentation de la jeunesse (Uneasy ages. Chinese cinemas: A representation of youth), Lyon, Tigre de Papier, 2009, 533 pp.

2 This work by Corrado Neri, based on his doctoral thesis, deals with the thematic treatment of youth in "Chinese language cinema." It is a historical and trans-territorial study of the representation of the youth in the cinematography of Taiwan, Hong Kong, and the People's Republic. By the term "youth," which may appear rather vague and culturally constructed, the writer means the transition from childhood to adulthood, and he focuses on the trials and rites of passage confronting the characters in these films. He has chosen to coin the expression Bildungsfilm as analogous to the Bildungsroman, the novel form that deals with the process leading from childhood to maturity. In Corrado Neri's view, the Bildungsfilm fills the same role as that Western literary genre, which arose "to give meaning to modernity" (p. 42). ${ }^{1}$ Moreover, this cinema appeared at a time when youth as an age group began to be seen as more important in political and social life. "The theme of youth was [then] reused in propaganda as an image of national utopian aspiration" (p. 32). The analysis of this cinematographic theme is equated by the author with an analysis of the development of Chinese society because, in his view, films dealing with youth are like the Bildungsroman, in that they provide "the most meaningful platform for understanding and assessing the historical 
development of an epoch" (p. 42). These are the theoretical premises from which Corrado Neri highlights four stages or "meanings" taken by the theme of youth in the historical development of these different cinemas. Within each of the four periods that give shape to his book, the author carries out comparative analyses of the way youth is represented, especially in the work of directors such as Tsai Ming-liang, Tsui Hark, Edward Yang, and Fei Mu.

The first section, entitled "avant-garde youth," deals with Chinese cinema before 1949. There, youth is portrayed as sometimes politically committed and conscious of the nation's problems, or as victims of the situation, but sometimes also as frivolous, as the characters are often enthusiastic about novelties introduced from the West (such as music, pastime pursuits, sports, and dancing). The Queen of Sports (Sun Yu, 1934), The Song of the Nation (Luo Mingyou and Zhu Shilin, 1935), Dawn (Sun Yu, 1933), and Boulevard Angels (Yuan Muzhi, 1937) figure prominently among the films analysed in this section.

The next section deals with "the youth state," and examines the paradoxically similar ways in which this theme was used for propaganda purposes in all three territories, even while they were politically opposed to each other. Although the purposes of these are clearly different, and convey quite distinct ideologies, the author draws a convincing parallel between the image of an ideal youth representing Confucian values in the "Healthy Realism" of the Taiwanese cinema and the revolutionary youth of the films made in the PRC (see, in particular, the discussion on Lee Hsing's Oyster Girl, 1963, and Wang Bin and Shui Hua's White-haired Girl, 1950). However, Hong Kong cinema, precisely because it was obliged to avoid political allusions, does not quite fit into this interpretive framework, and has left us with works that are both more commercial and more violent (in the wuxiapian, or martial arts, genre), and in which the characters are not just creatures made to serve a purpose.

The "reinvented youth" category corresponds to the 1980s, with its "democratisation" process common to all three territories, and the arrival on the cinema scene of new directors such as Zhang Yimou and Chen Kaige in the PRC, Tsui Hark and John Woo in Hong Kong, and Edward Yang in Taiwan. In their works, the representation of youth sheds its instrumental bias to show the awakening of individual and historical consciousness in the PRC (Chen Kaige's Yellow Earth, 1984), to reflect on the motherland and identity in Taiwan (Hou Hsiao Hsien's A Time to Live, a Time to Die, 1985), and to convey the contradictory emotions of attachment and rejection with regard to China in Hong Kong (Tsui Hark's Don't Play with Fire, 1980).

The volume ends with the chapter on "youth in the 1990s," which is mainly concerned with the sixth generation of directors in China and the work of Tsai Ming-liang in Taiwan. The Bildung perspective becomes questionable in the case of these more recent films, since they show individuals who simply stagnate (in Jia Zhangke's films), or who 
reach adulthood through a brutal process that seems to lead into a world of disillusionment and hopelessness (as in Li Yang's Blind Shaft).

As the book develops and the writer turns away from the chronological ordering of his film analyses, he shows that the way of representing young people is linked not only to the conceptions that the creators have of youth in general, but also of their own youth, and to whether they are still experiencing it or showing it in retrospect. Tsai Ming-liang in particular sets up an interplay between his own biography, that of his favoured actor Lee Kang-sheng, and the on-screen character that he plays -- like the Truffaut-Léaut couple -- thus creating, in his own words, "a diary written onto the skin of a son, who in his turn comes to bear the indelible traces of his adoptive father" (p. 438).

Contrary to the impression given by Corrado Neri's sociological approach at the beginning of his book, the development of his argument on the theme of youth is not only linked to the symbolic value of that age group or to a vision of society, but sometimes also to highly personal reflections (as in the case of Tsai Ming-liang) as well as to a certain conception of the cinema and its role. In Neri's view, the 1980s in the PRC gave a greater opportunity to the cinema to pursue its own Bildung-process through to maturity, rather than to merely provide examples of such growth through the characters in the films. This was the time when Chinese cinema (in all three territories, but particularly in the PRC) threw off its role as a propaganda tool. When filmed by Zhang Yimou, the "polysemic" body of Gong Li, the bearer of traditional values as well as the wounds of history (in Red Sorghum, 1987, and Judou, 1990), introduced an element of youthful subversion into his oeuvre. Without emphasising youthfulness as such -- since his scripts do not look back to classical Bildung plots -- Zhang Yimou was able to insert a purely cinematographic form of dissent into his films in the 1980s, thanks to that leading actress whose body was the vehicle for such contradictory values. Cinema, combining within itself the properties of medium, message, and object of aesthetic research, then becomes the incarnation of youth itself in its recent history, and in its ability to overturn the established order after throwing off its political or commercial restraints, allowing it to assume the role of a young and "rebellious" art. This tendency to abandon the Bildung format seems to have become more pronounced in the PRC over the following decade. In that period, while onscreen characters remain youthful, they never seem to achieve any final maturity, and the screenplays tend to be openended and ambiguous.

Despite the writer's careful attempt to arrange the films according to period and the "meanings" attributed to youth, it is sometimes difficult to grasp the unity within each chapter, so great is the variation on this theme in the works themselves. The author occasionally blurs or plays down differences between the three distinct cinema practices and highlights certain supposedly shared features in an effort to make a point about the societies in which they are 
embedded and to smooth the way for the overall periodisation. Moreover, the author's association of the filmic characters' family situation and the relationship between the three territories (China standing in for the parents, and Taiwan or Hong Kong for the younger generation) seems somewhat forced. The more the author develops his analysis, the more complicated the idea of youth seems to become, and the less consistent with his theoretical framework. The three cinemas he studies here become increasingly distant from social or symbolic interpretations as they free themselves from the political or commercial contingencies that weigh upon them. The most successful parts of this book are ultimately those in which the author also distances himself from the initial sociological approach, and handles his theme in purely cinematographic terms by examining the relationship between director, actor, and medium.

The difficulty of drawing conclusions (paradoxically a good sign) in this essay on youth in Chinese cinema shows that it is preferable to approach the material film by film, and director by director, while avoiding an approach to cinema as a simple manifestation of phenomena that transcend it. Still, although the reader may question Corrado Neri's method and initial proposal (to make use of the Bildungsfilm to observe the development of three societies), it must be acknowledged that the enormous comparative work he has undertaken allows him to highlight certain distinctive trends, and that his thematic "reading" of this large body of work provides a good basis for reflecting on questions of method in the discipline of cinematographic studies. The latter still lacks a well established approach and reliable guidelines, since it is, after all, not yet a fully developed discipline.

Translated by Jonathan Hall

\section{NOTES}

1. Franco Moretti, Il romanzo di formazione, Torino, Einaudi 1999, p. 5, 